Gut, 1985, 26, 667-671

\title{
Antibodies to gliadin detected by immunofluorescence and a micro-ELISA method: markers of active childhood and adult coeliac disease
}

\author{
U VOLTA, M LENZI, ROSANNA LAZZARI, F CASSANI, ANGELA COLLINA, \\ F B BIANCHI, AND E PISI
}

From the Istituto di Patologia Medica I and Istituto di Clinica Pediatrica III, University of Bologna, Bologna, Italy

SUMMARY Antibodies to gliadin have been detected by immunofluorescence (IFL-AGA) and a micro-ELISA method (ELISA-AGA) in 45 out of $47(96 \%)$ sera from patients with active childhood and adult coeliac disease. The two methods were more sensitive than $R_{1}$-reticulin antibodies ( $R_{1}$-ARA) which were found only in 28 of the same patients $(60 \%)$. $R_{1}$-ARA were always negative in the 26 sera from patients with childhood coeliac disease and adult coeliac disease after gluten free diet, while IFL- and ELISA-AGA were respectively found in three (12\%) and in four $(15 \%)$ out of these patients. Moreover, while $\mathrm{R}_{1}$-ARA and IFL-AGA were strictly confined to coeliac disease, ELISA-AGA were occasionally found in patients with control diseases. These 'false positive' antibodies were all of IgG class and had low titres. In our experience IFL- and ELISA-AGA of IgA class were strictly confined to active childhood coeliac disease and adult coeliac disease. The detection of AGA is useful in monitoring the diet and in the follow up of coeliac disease. IFL- and ELISA-AGA, then, are to be preferred to $\mathrm{R}_{1}-\mathrm{ARA}$ for the screening of coeliac patients.

Circulating antibodies to reticulin and gliadin have been described in sera from patients with childhood and adult coeliac disease. ${ }^{2}$

$\mathrm{R}_{1}$-reticulin antibodies $\left(\mathrm{R}_{1}\right.$-ARA), detected by immunofluorescence, have been detected in active childhood coeliac disease and adult coeliac disease with a prevalence varying from $36 \%$ to $78 \%$. $^{3-6}$ Because of the low sensitivity, $R_{1}$-ARA have proved of limited value in the diagnosis of gluten enteropathy. Their specificity, however, has been reported as high, although rare 'false positive' cases have been described in Crohn's disease and dermatitis herpetiformis. ${ }^{78}$

Antibodies to gliadin, detected by immunofluorescence (IFL-AGA) and recently by a micro-ELISA method (ELISA-AGA), appear to be far more sensitive, though less specific, than $\mathrm{R}_{1}$-ARA, being also found in 'control' gastroenterological disorders. In fact, IFL-AGA

Address for correspondence: Dr Umberto Volta, Istituto di Patologia Medica I, Policlinico S Orsola, Via Massarenti 9, 40138 Bologna. Italy.

Received for publication 3 August 1984 were present in $100 \%$ of sera from 32 children with childhood coeliac disease on free diet or after gluten challenge ${ }^{9}$ and ELISA-AGA were found by Savilahti et $_{\text {al }}{ }^{10}$ in all the 11 children (aged under 2 years) with untreated childhood coeliac disease. Antibodies to gliadin were also found in some cases of Crohn's disease, ulcerative colitis, cow's milk enteropathy, transient gluten intolerance and dermatitis herpetiformis. ${ }^{911}$ 12

$R_{1}$-ARA, IFL- and ELISA-AGA were confined to IgA and IgG class. ${ }^{125}{ }^{10}$ Moreover, $R_{1}$-ARA and ELISA-AGA of IgA class were only present, with few exceptions, in patients with active coeliac disease..$^{5} 10$

The aim of this work was to define the relevance of $R_{1}$-ARA, IFL- and ELISA-AGA in the diagnosis of childhood coeliac disease and adult coeliac disease. Therefore, we have compared the immunofluorescence and the micro-ELISA methods, evaluating their sensitivity and specificity, to establish which of the three antibodies proved to be more useful for the screening of coeliac patients. 


\section{Methods}

PATIENTS

A total of 309 sera was studied. Fifty seven sera from patients with childhood coeliac disease (aged 2-10 years) and 16 sera with adult coeliac disease, at different stages of the disease, diagnosed according to defined criteria, ${ }^{13}$ were tested. They included 24 sera from patients with untreated and newly diagnosed childhood coeliac disease, 22 from patients after one year of gluten free diet and 11 from patients after two months of gluten challenge. Sera from adult coeliac disease patients came from 12 untreated cases and four after one year of gluten free diet. In all coeliac disease cases the diagnosis was based on the intestinal biopsy. In the 36 newly diagnosed patients subtotal villous atrophy was found in 34 and partial villous atrophy in two. All the 26 patients biopsied after one year of gluten free diet showed a normal villous morphology, while 10 of the 11 patients studied after two months of gluten challenge displayed a subtotal villous atrophy and one a partial villous atrophy.

As control diseases, sera from 191 patients with various intestinal and non-intestinal pathological conditions associated with immunological abnormalities were tested. They included sera from 40 children (15 with postenteritis syndrome and 25 with $\operatorname{IgA}$ deficiency) and from 151 adults (31 with ulcerative colitis, 15 with Crohn's disease, 55 with primary biliary cirrhosis and autoimmune chronic hepatitis and 50 with rheumatoid arthritis). Patients with intestinal involvement had a peroral biopsy which excluded villous abnormalities. Thirty sera from healthy children and 15 from blood donors, sex and age matched with childhood coeliac disease and adult coeliac disease patients respectively, were also studied.

R - ARA

Diluted $(1: 10)$ sera were tested by immunofluorescence using a fluorescein isothiocyanate conjugated sheep antihuman $F(a b)_{2}$ serum (Wellcome) on $5 \mu$ cryostat sections of rat liver, kidney, and stomach. ${ }^{14}$ Positive sera were also tested on human liver sections, surgically taken from blood $\mathrm{O}$ group patients who underwent operation for gall bladder stones. Monospecfic rabbit anti-human fluorescein isothiocyanate conjugated IgG, IgA and IgM sera (Behringwerke) were used to assess the Ig class of the antibodies. Positive sera were titred to end-point by immunofluorescence. Slides were read under a Leitz microscope with vertical illumination (Xenon XBO 75W lamp).
IFL-AGA

Antibodies to gliadin were detected by a modification of the immunofluorescence method described for $R_{1}$-ARA. ${ }^{915}$ Cryostat sections were pretreated with an aqueous solution of crude gliadin (Sigma) $(0 \cdot 1 \mathrm{mg} / \mathrm{ml})$ for 30 minutes. After washing in phosphate buffered saline to remove unbound wheat protein, gliadin treated sections were processed as for $R_{1}$-ARA.

\section{ELISA-AGA}

The micro-ELISA test used in this study was modified from that described by Lenzi et al. ${ }^{16}$ Briefly, the standard coating conditions were as follows: $200 \mu \mathrm{l}$ of crude gliadin (Sigma) at the concentration of $0.1 \mathrm{mg} / \mathrm{ml}$ in $0.005 \mathrm{M}$ carbonate buffer, $\mathrm{pH} 9 \cdot 6$, were seeded in each well of microplates (Dynatech 129) and incubated overnight at $4^{\circ} \mathrm{C}$. Wells were then washed three times with phosphate buffered saline containing $0.5 \%$ Tween 20. Two hundred microlitres of patients' serum, previously diluted with phosphate buffered saline (1:500 and 1:100 respectively for the detection of $\operatorname{IgG}$ and $\operatorname{IgA}$ antibodies), were added to each gliadin-coated well. Incubation was carried out for three hours at room temperature. After three washings, $200 \mu \mathrm{l}$ of alkaline phosphatase conjugated rabbit anti-human IgG (raised, isolated by affinity chromatography using commercially available IgG - Miles - as antigen and conjugated with alkaline phosphatase - Sigma - in our laboratory) and alkaline phosphatase-conjugated rabbit anti-human IgA (Sigma) were added to each well and left at room temperature for three hours. Alkaline phosphatase activity bound to the wells was then measured by adding $200 \mu \mathrm{l}$ of fresh substrate solution (P-nitrophenyl disodium phosphate) in diethanolamine buffer $\mathrm{pH} 9 \cdot 8$. After incubation at room temperature for 30 minutes the reaction was stopped by adding $50 \mu \mathrm{l}$ of $3 \mathrm{M} \mathrm{NaOH}$ and absorbance was measured by a Dynatech micro-ELISA autoreader MR 580. In these experiments optimal gliadin concentration and serum dilution were used according to previously determined titration curves, showing that optimal optical density values were obtained with concentrations and dilutions used.

\section{Results}

Results are reported in the Table.

$R_{1}$-ARA were detected in only $12(50 \%)$ of the 24 children with untreated childhood coeliac disease. These antibodies were also found in seven $(64 \%)$ of the 11 children with childhood coeliac 
Table Prevalence of $R_{I}-A R A, I F L$ - and ELISA-AGA in the 309 sera tested

\begin{tabular}{|c|c|c|c|c|c|c|c|c|c|c|}
\hline & \multirow[b]{2}{*}{ No } & \multicolumn{3}{|c|}{$I F L-A G A$} & \multicolumn{3}{|c|}{$E L I S A-A G A$} & \multicolumn{3}{|l|}{$R_{l}-A R A$} \\
\hline & & $\operatorname{Ig} A(\%)$ & $\operatorname{Ig} G(\%)$ & Total (\%) & $\operatorname{IgA}(\%)$ & $\lg G(\%)$ & Total $(\%)$ & $\operatorname{Ig} A(\%)$ & $\operatorname{Ig} G(\%)$ & Total (\%) \\
\hline $\begin{array}{l}\text { Childhood coeliac disease (CCD) } \\
\text { newly diagnosed, untreated } \\
\text { confirmed after gluten challenge } \\
\text { after } 1 \text { year on gluten free diet }\end{array}$ & $\begin{array}{l}24 \\
11 \\
22\end{array}$ & $\begin{array}{l}71 \\
64 \\
-\end{array}$ & $\begin{array}{l}54 \\
36 \\
14\end{array}$ & $\begin{array}{r}100 \\
91 \\
14\end{array}$ & $\begin{array}{r}79 \\
63 \\
5\end{array}$ & $\begin{array}{r}100 \\
82 \\
18\end{array}$ & $\begin{array}{r}100 \\
91 \\
18\end{array}$ & $\begin{array}{l}29 \\
36 \\
-\end{array}$ & $\begin{array}{l}21 \\
27 \\
-\end{array}$ & $\begin{array}{l}50 \\
64 \\
-\end{array}$ \\
\hline $\begin{array}{l}\text { Adult coeliac disease }(A C D) \\
\text { newly diagnosed, untreated } \\
\text { after } 1 \text { year on gluten free diet }\end{array}$ & $\begin{array}{r}12 \\
4\end{array}$ & $\frac{58}{-}$ & 33 & $\begin{array}{c}92 \\
-\end{array}$ & $\frac{58}{-}$ & $\begin{array}{l}92 \\
50\end{array}$ & $\begin{array}{l}92 \\
50\end{array}$ & $\frac{42}{-}$ & 33 & $\frac{75}{-}$ \\
\hline $\begin{array}{l}\text { Disease controls } \\
\text { Postenteritis syndrome } \\
\text { IgA deficiency } \\
\text { Ulcerative colitis } \\
\text { Crohn's disease } \\
\text { Primary biliary cirrhosis and } \\
\text { autoimmune chronic hepatitis } \\
\text { Rheumatoid arthritis }\end{array}$ & $\begin{array}{l}15 \\
25 \\
31 \\
15 \\
55 \\
50\end{array}$ & $\begin{array}{l}- \\
- \\
-\end{array}$ & $\begin{array}{l}- \\
- \\
- \\
-\end{array}$ & $\begin{array}{l}- \\
- \\
- \\
-\end{array}$ & $\begin{array}{l}- \\
- \\
- \\
-\end{array}$ & $\begin{array}{r}20 \\
4 \\
10 \\
13 \\
- \\
-\end{array}$ & $\begin{array}{r}20 \\
4 \\
10 \\
13 \\
- \\
-\end{array}$ & $\begin{array}{l}- \\
- \\
- \\
-\end{array}$ & $\begin{array}{l}- \\
- \\
- \\
-\end{array}$ & $\begin{array}{l}- \\
- \\
- \\
-\end{array}$ \\
\hline All disease control cases & 191 & - & - & - & - & 5 & 5 & - & - & - \\
\hline All healthy control cases & 45 & - & - & - & - & - & - & - & - & - \\
\hline
\end{tabular}

disease after gluten challenge and were never observed in the 22 with childhood coeliac disease after gluten free diet. Of the 12 patients with untreated adult coeliac disease, nine $(75 \%)$ were positive for $R_{1}$-ARA, while the four with adult coeliac disease after gluten free diet were negative. None of the 191 control disease patients, as well as the 45 healthy controls, turned out to be positive. $\mathrm{R}_{1}$-ARA titres varied from 1:20 to $1: 320$ with a slight prevalence of IgA antibodies.

IFL-AGA were found in $100 \%$ children with untreated childhood coeliac disease, in $91 \%$ cases after gluten challenge and in three $(14 \%)$ cases after gluten free diet. IFL-AGA were detected in $11(92 \%)$ patients with untreated adult coeliac disease: none of the four adult coeliac disease patients after gluten free diet was positive. All the 191 sera from control disease patients and the 45 from healthy controls were negative. IFL-AGA showed the same immunofluorescence pattern of $\mathrm{R}_{1}$-ARA. Though their titres were slightly higher (ranging from 1:20 to 1:640) no significant difference with $R_{1}$-ARA titres was shown. Moreover, IFL-AGA were more frequently confined to the IgA class (66\%).

ELISA-AGA were detected in $100 \%$ untreated childhood coeliac disease and in $91 \%$ childhood coeliac disease after gluten challenge. They were also present in four (18\%) cases of childhood coeliac disease after gluten free diet and in all these patients the antibodies were of IgG class, associated to IgA in one case only. ELISA-AGA were observed in $11(92 \%)$ of the 12 untreated adult coeliac disease and also two of the four cases after gluten free diet were positive. In control disease groups ELISA-AGA were found in three $(20 \%)$ of the 15 sera from patients with postenteritis syndrome, in two $(13 \%)$ of the 15 with Crohn's disease, in three $(10 \%)$ of the 31 with ulcerative colitis and in one (4\%) of the 25 with IgA deficiency. These antibodies were always confined to IgG class. The results of the healthy controls were negative. The ELISA-AGA titres turned out to be far higher in the sera from untreated coeliac patients and among these in childhood coeliac disease than in adult coeliac disease subjects (Figure).

The statistical analysis ( $\chi^{2}$, Yates' correction) showed a significant difference between IFL-/ELISA-AGA and $R_{1}$-ARA in childhood coeliac disease $(p<0.005)$, and IgG ELISA-AGA and IgG IFL-AGA both in childhood coeliac disease $(p<0.005)$ and in adult coeliac disease $(\mathrm{p}<0.05)$.

As most patients with active coeliac disease (both newly diagnosed and after gluten challenge) had the highest histological degree of mucosal damage, no attempt was made to correlate histological results and titres of the various antibodies tested. The three cases with partial villous atrophy had low titre antibodies, both in immunofluorescence and ELISA.

\section{Discussion}

Both IFL- and ELISA-AGA turned out to be more 
sensitive than $R_{1}$-ARA in diagnosing childhood coeliac disease and adult coeliac disease. $R_{1}$-ARA were, however, strictly confined to childhood coeliac disease and adult coeliac disease, as did IFL-AGA, while ELISA-AGA were occasionally found in disease control patients. $R_{1}$-ARA and IFL-AGA showed the same reticulin pattern and, when the two antibodies were present in the same serum, antibodies to gliadin titre was higher than $\mathrm{R}_{1}$-ARA titre.

IFL- and ELISA-AGA showed a very similar sensitivity, while IFL-AGA were slightly more specific than ELISA-AGA. Unlike Unsworth et $a l^{911}$ we could not find IFL-AGA in groups other than childhood coeliac disease and adult coeliac disease. The low prevalences of IFL- and ELISA-AGA and $R_{1}$-ARA in the gluten free diet subgroup are probably because our patients were tested after a longer period of gluten free diet (one year instead of three months, as in other works). ${ }^{19}$ Both sensitivity and specificity of $\operatorname{IgA}$ and $\operatorname{IgG}$ antibodies were similar for IFL-AGA, while IgG ELISA-AGA were more sensitive than IgG IFL-AGA both in childhood coeliac disease and in adult coeliac disease.

In our experience IgA AGA, detected both by ELISA and immunofluorescence, were strictly confined to active coeliac disease, as all the 'false positive' antibodies to gliadin, shown by ELISA method, were of IgG class. It is also interesting to remark that these 'false positives' were less than $5 \%$ in control disease groups and that their titre was very low (Figure).

The presence of antibodies to gliadin, especially of IgA class, warrants a jejunal biopsy in children and adults with suspected coeliac disease even if

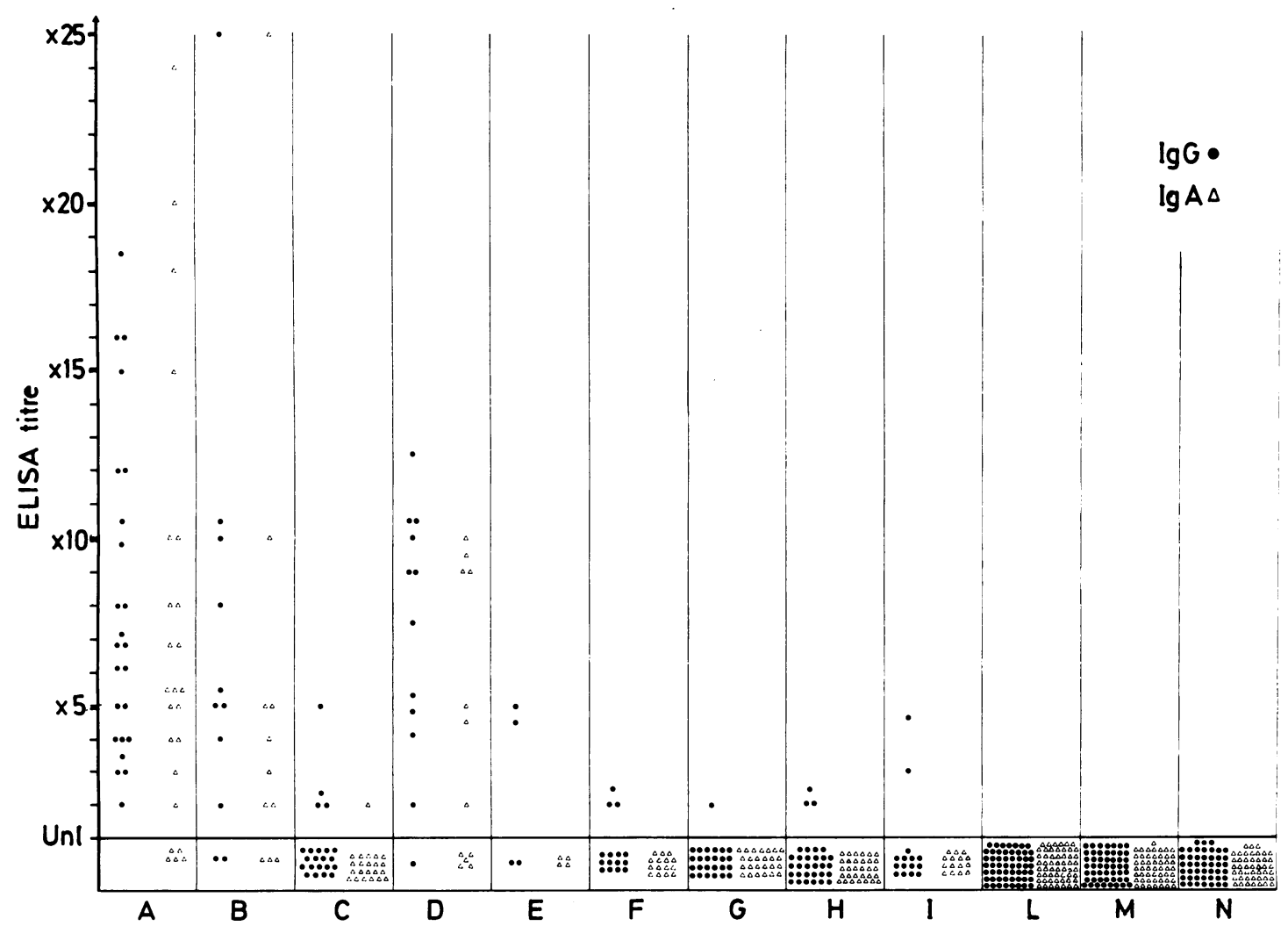

Figure ELISA titres of serum antibodies to gliadin (ELISA-AGA) unl (upper normal limit) $=x+3 S D$ of controls.

$A=$ untreated childhood coeliac disease (CCD).

$B=C C D$ after gluten challenge.

$C=C C D$ on gluten free diet.

$D=.004$ untreated adult coeliac disease $(A C D)$.

$E=A C D$ on gluten free diet .

$F=$ postenteritis syndrome.
$G=I g A$ defieciency.

$H=$ ulcerative colitis.

$I=$ Crohn's disease.

$L=$ primary biliary cirrhosis and autoimmune chronic hepatitis.

$M=$ rheumatoid arthritis.

$N=$ healthy controls. 
other parameters are negative. Moreover, as a positive antibodies to gliadin test is closely related to the active phases of childhood coeliac disease and adult coeliac disease, their research can be useful both to evaluate the effect of gluten free diet and to establish when a new biopsy is appropriate after gluten challenge.

On the whole, IFL- and ELISA-AGA should be preferred to $R_{1}$-ARA for the screening of coeliac patients; the two tests give similar results and the choice of one of the two depends on the facilities available in each laboratory.

\section{References}

1 Unsworth DJ, Kieffer M, Holborow EJ, Coombs RRA, Walker-Smith JA. IgA anti-gliadin antibodies in coeliac disease. Clin Exp Immunol 1981; 46: 286-93.

2 Eterman KP, Feltkamp TEW. Antibodies to gluten and reticulin in gastrointestinal diseases. Clin Exp Immunol 1978; 31: 92-9.

3 Seah PP, Fry L, Holborow EJ et al. Antireticulin antibody: incidence and diagnostic significance. Gut 1973; 14: 311-5.

4 Mallas EG, Williamson N, Cooper BT, Cooke, WT. IgA class reticulin antibodies in relatives of patients with coeliac disease. Gut 1977; 18: 647-50.

5 Eade OE, Lloyd RS, Lang C, Wright R. IgA and IgG reticulin antibodies in coeliac and non-coeliac patients. Gut 1977; 18: 991-3.

6 Lazzari R, Volta U, Masi M et al. $\mathrm{R}_{1}$ antireticulin antibody: probable marker of childhood coeliac disease on a normal diet and on gluten challenge. Ital $J$ Gastroenterol 1982; 14: 59.

7 Alp MH, Wright R. Autoantibodies to reticulin in patients with idiopathic steatorrhoea, coeliac disease and Crohn's disease, and their relation to immunoglobulins and dietary antibodies. Lancet 1971; 25: $682-5$.

8 Lancaster-Smith M, Kumar P, Clark ML, Marks R, Johnson GD. Antireticulin antibodies in dermatitis herpetiformis and adult coeliac disease. Br J Dermatol 1975; 92: 37-42.

9 Unsworth DJ, Manuel PD, Walker-Smith JA, Campbell CA, Johnson GD, Holborow EJ. New immunofluorescent blood test for gluten sensitivity. Arch Dis Child 1981; 56: 864-8.

10 Savilahti E, Perkkio M, Kalimo K, Viander M, Vainio $\mathrm{E}$, Reunala $\mathrm{T}$. IgA antigliadin antibodies: a marker of mucosal damage in childhood coeliac disease. Lancet 1983; 12: 320-2.

11 Unsworth DJ, Walker-Smith JA, Holborow EJ. Gliadin and reticulin antibodies in childhood coeliac disease. Lancet 1983; 16: 874-5.

12 Huff JC, Weston WL, Zirker DK. Wheat protein antibodies in dermatitis herpetiformis. $J$ Invest Dermatol 1979; 73: 570-4.

13 Anonymous. Confirming the diagnosis of coeliac disease [Editorial]. $\mathrm{Br}$ Med J 1975; 4: 2.

14 Rizzetto M, Doniach D. Types of 'reticulin' antibodies detected in human sera by immunofluorescence. $J$ Clin Pathol 1973; 26: 841-51.

15 Unsworth DJ, Johnson GD, Haffenden G, Fry L, Holborow EJ. Binding of wheat gliadin in vitro to reticulin in normal and dermatitis herpetiformis skin. $J$ Invest Dermatol 1981; 76: 88-93.

16 Lenzi M, Cassani F, Bianchi FB, Franceschi C. A micro-ELISA assay to detect anti-liver-specific protein antibodies in the sera of patients with liver diseases. J Immunol Methods 1983; 57: 59-69. 